\title{
Chapter 26 \\ South Africa as a Donor of Naturalised and Invasive Plants to Other Parts of the World
}

\author{
Petr Pyšek (D, Jan Pergl (D, Mark van Kleunen (D, Wayne Dawson (D, \\ Franz Essl (D), Holger Kreft (D), Patrick Weigelt (D, John R. Wilson (D, \\ Marten Winter (D), and David M. Richardson
}

\author{
P. Pyšek $(\bowtie)$ \\ Department of Invasion Ecology, Institute of Botany, Czech Academy of Sciences, \\ Průhonice, Czech Republic \\ Department of Ecology, Faculty of Science, Charles University, Prague, Czech Republic \\ Centre for Invasion Biology, Department of Botany and Zoology, Stellenbosch University, \\ Stellenbosch, South Africa \\ e-mail: petr.pysek@ibot.cas.cz \\ J. Pergl \\ Department of Invasion Ecology, Institute of Botany, Czech Academy of Sciences, \\ Průhonice, Czech Republic \\ M. van Kleunen \\ Department of Biology, University of Konstanz, Constance, Germany
}

Zhejiang Provincial Key Laboratory of Plant Evolutionary Ecology and Conservation, Taizhou University, Taizhou, China

W. Dawson

Department of Biosciences, Durham University, Durham, UK

F. Essl

Centre for Invasion Biology, Department of Botany and Zoology, Stellenbosch University, Stellenbosch, South Africa

Division of Conservation Biology, Vegetation and Landscape Ecology, University of Vienna, Vienna, Austria

H. Kreft · P. Weigelt

Biodiversity, Macroecology and Biogeography, University of Göttingen, Göttingen, Germany

J. R. Wilson

Centre for Invasion Biology, Department of Botany and Zoology, Stellenbosch University, Stellenbosch, South Africa

South African National Biodiversity Institute, Kirstenbosch Research Centre, Cape Town, South Africa

B. W. van Wilgen et al. (eds.), Biological Invasions in South Africa, Invading

Nature - Springer Series in Invasion Ecology 14,

https://doi.org/10.1007/978-3-030-32394-3_26 


\begin{abstract}
This chapter provides the first assessment of South African native vascular plants as naturalised and invasive species in other parts of the world. For naturalised species, Global Naturalized Alien Flora (GloNAF) data were used, while for invasive species an assessment was made using the peer-reviewed literature, experience of the authors, and correspondence with authorities in many parts of the world. Results show that 1093 South African native plant taxa have been recorded as naturalised, but for only 79 of these is there strong and unequivocal evidence of invasiveness in natural or semi-natural ecosystems (another 132 taxa have been listed as invasive, but do not fulfil all criteria for listing as such). Thirty-five taxa have naturalised in more than 100 regions (countries, states, provinces, districts, or individual islands), and six taxa (all grasses-family Poaceae) are naturalised in more than 200 regions. However, of these, only $12(34.2 \%)$ are recorded as invasive, and only nine fulfil the more conservative definition of invasive. These figures indicate that to be widely distributed does not automatically translate into being a strong invader, and that taxa that are extremely successful as invaders in some regions only succeed in specific environmental and geographic settings, and many of them are not widespread alien plants. Grasses are over-represented among both naturalised and invasive South African plant exports: $15 \%$ of naturalised species and $23 \%$ of invasive species are grasses. Temperate Asia and Europe are net donors of naturalised plants to South Africa, but Australasia and the Pacific Islands have received many more naturalised plants than they have donated to South Africa. Of taxa native to South Africa recorded as unequivocally invasive outside of cultivation elsewhere, $65 \%$ occur in Australia.
\end{abstract}

\title{
26.1 Introduction
}

Information on the global distribution of alien plant species has improved dramatically over the last decade (van Kleunen et al. 2015; Pyšek et al. 2017), largely due to the Global Naturalized Alien Flora database (GloNAF; www.glonaf.org) that integrates and summarises the wealth of regional data on the occurrence of naturalised alien plants worldwide (sensu Richardson et al. 2000b). In January 2019, GloNAF contained data on the distribution of 13,939 plant taxa in 1029 regions, including 381 islands (the regions in GloNAF correspond to countries, states, provinces, districts, or individual islands, see van Kleunen et al. 2019 for the full list). GloNAF has been used for testing a wide range of central concepts and hypotheses in invasion biology (see Pyšek et al. 2017 for an overview, and Kalusová et al. 2017; Guo et al. 2018; Haeuser et al. 2018; Moser et al. 2018; Pyšek et al. 2019; Razanajatovo et al. 2019 for recent results). It has

\author{
M. Winter \\ German Centre for Integrative Biodiversity Research (iDiv) Halle-Jena-Leipzig, Leipzig, \\ Germany \\ D. M. Richardson \\ Centre for Invasion Biology, Department of Botany and Zoology, Stellenbosch University, \\ Stellenbosch, South Africa
}


also served as a reference point for elaborating updated checklists and for conducting analyses of naturalised and invasive floras of understudied regions (Inderjit et al. 2018; Vinogradova et al. 2018; Ansong et al. 2019).

South Africa has always played a prominent role in research on biological invasions, both among countries on the African continent and globally (Pyšek et al. 2006, 2008), being the country with the strongest tradition of recording and studying both native and alien floras. The ecology and biogeography of plant invasions in South Africa has been well studied (Richardson et al. 1997, 2005, 2020). However, much less is known about how South Africa's native flora contributes to invasions elsewhere, by supplying naturalised and invasive species to other parts of the world. Conditions similar to those that occur in South Africa's terrestrial biomes occur over large parts of the world (Thuiller et al. 2005; Richardson and Thuiller 2007; Fig. 1.3 in van Wilgen et al. 2020, Chap. 1). For example, Thuiller et al. (2005) combined bioclimatic modelling and the assessment of propagule pressure (using metrics of the extent of trade and tourism between South Africa and other parts of the world as proxies) to predict the risk of South African plant species becoming invasive elsewhere in the world. They modelled the invasion risk for 96 native South African plant taxa, and projected them globally for three invasive species of South African origin [Ice Plant (Carpobrotus edulis), Woad-leaved Ragwort (Senecio glastifolius), and White Cudweed (Vellereophyton dealbatum)]. This study showed that high-risk regions closely match global hotspots of plant biodiversity (Thuiller et al. 2005).

Several South African plant species are well known invasive species, and feature prominently in the global invasion literature. For example, Carpobrotus edulis is included in a list of the 50 "most intensively studied invasive species" (Pyšek et al. 2008). This species and Andropogon gayanus (Gamba Grass), Cenchrus ciliaris (Buffel-Grass) and Chrysanthemoides monilifera (Bitou-bush) are included on a list of 23 invasive plant species that have been recorded as driving regime shifts in invaded ecosystems (Gaertner et al. 2014). Several South African native species also appear on regional lists of the most damaging invasive plant species. For example, 12 out of 32 taxa listed as "Weeds of National Significance" in Australia (www.environment. gov.au/biodiversity/invasive/weeds/weeds/lists/wons.html) have South Africa as part of their native range. Two South African species (Carpobrotus edulis and Chrysanthemoides monilifera) are included in a list of the most noxious invasive plant species in protected areas around the world (Foxcroft et al. 2017). Oxalis pes-caprae (Bermuda Buttercup) is included in the list of "the 10 invasive species [...] with the highest number of different impact types on ecosystem services in Europe" (Vilà et al. 2010). Despite the recognition of South Africa as an important donor of naturalised and invasive plants, no systematic analysis of the contribution of this region to the global naturalised and invasive flora has been attempted. This chapter addresses this knowledge gap. 


\subsection{Methodological Assumptions}

Assessing the contribution of a region to naturalised and invasive floras presents separate logistical challenges. In terms of the definitions that are widely accepted for distinguishing naturalised from invasive species (Richardson et al. 2000b), naturalised species reproduce regularly in areas well outside their native ranges where they have been introduced through human activity, whereas invasive species have also spread over substantial distances from introduction sites. Invasive species are thus a subset of the naturalised flora. However, these definitions are not used consistently between databases, publications, and countries. Importantly, therefore, this study focussed only on data sources that conformed to the above definitions.

\subsubsection{Naturalised Species: the GloNAF Database}

We use the GloNAF database (van Kleunen et al. 2019) to analyse South Africa's contribution to the global naturalised flora, and to evaluate the recipient-donor dynamics and exchange of this country's flora with other regions of the world. The GloNAF database includes naturalised plant taxa that correspond to the above definition, and that are reported as such from at least one region of the world (van Kleunen et al. 2015, 2019; Pyšek et al. 2017). This database draws on national/ regional floras and applies standard selection criteria globally, which makes it the most comprehensive and robust source currently available (Rejmánek 2015). Using one large database like GloNAF enables us to evaluate the contribution of South Africa to the world's naturalised flora, and to compare this with the contribution of different regions to South Africa's naturalised flora.

\subsubsection{Invasive Species}

GloNAF does not, however, allow for the elucidation of invasive floras, as different criteria are used to denote the separation of naturalised from invasive in different parts of the world, and the information on invasive species in GloNAF is much less complete (Pyšek et al. 2017). For this reason, we compiled, de novo, a list of South African native plant taxa that are invasive in natural and semi-natural ecosystems in other regions, by reviewing the literature [including the list of invasive trees compiled by Rejmánek and Richardson (2013)], drawing on our own experience, and from corresponding with authorities in many parts of the world. This list was then compared with the one given by Weber (2017) that includes species deemed invasive in natural or semi-natural ecosystems all over the world.

At present, there is no global list of invasive plant taxa compiled with the same level of precision as that for naturalised taxa. The Global Registry of Introduced and 
Invasive Species (www.griis.org; Pagad et al. 2018) will hopefully provide accurate country-level lists of invasive species in the future, but this is not yet available for our purpose here (and the definition of invasive currently used by GRIIS requires explicit evidence of impact, and therefore differs from that used in this paper). Consequently, we cannot contrast the role of South Africa as a donor of invasive species with the role of other regions of the world as donors. Nonetheless, this analysis provides the first systematic assessment of South Africa as a donor of invasive plants.

\subsubsection{Assuming a South African Origin}

We assume that if a species is native to South Africa and naturalised or invasive elsewhere then South Africa is the donor region. This is not always the case. For example, invasive populations of Vachelia nilotica (Thorn Mimosa) in Australia comprise genetic entities from southern Asia and Middle Asia (mostly Vachelia nilotica subsp. indica; Wardill et al. 2005), and there is no evidence that genetic entities that are invasive in Australia are native to South Africa (although South Africa is part of the native range of the species). This inclusive approach has been followed elsewhere (see Measey et al. 2020, Chap. 27). In contrast, a taxon might have a native range much broader than South Africa, but alien populations may have clearly come from South Africa, or belong to a subspecific entity that is endemic to South Africa. For example, the range of Chrysanthemoides monilifera extends from South Africa to Kenya, but at least two of the taxa that are invasive in Australia (called Bitou Bush and Boneseed), are subspecific entities that are endemic to South Africa (Beaumont et al. 2014). In the analyses in this chapter we ignore such complexities.

\subsection{South Africa's Contribution to the Global Naturalised Alien Flora}

In the GloNAF database, South Africa has 1139 naturalised alien plant species (Pyšek et al. 2017), and 1093 taxa that are native to South Africa are naturalised somewhere else in the world. This means that the country has slightly fewer naturalised aliens that it donates to other countries all over the world. Since there are 21,643 plant taxa native to South Africa of which 16,507 are endemic to southern Africa (South African National Biodiversity Institute 2016), 4.8\% of total plant richness in South Africa is alien somewhere else in the world (Pyšek et al. 2017). Related to the total number of species in the recent edition of the GloNAF database (van Kleunen et al. 2019), South Africa harbours $8.2 \%$ of the global naturalised flora. 
Thirty-five species native to South Africa have become particularly widespread and are currently naturalised in more than 100 GloNAF regions, and six species are naturalised in more than 200 regions - all of the latter are grasses: Eleusine indica (Indian Goosegrass; present in 332 regions; 35\% of the regions enumerated), Cynodon dactylon (Bermuda Grass; 307), Echinochloa crus-galli (Barnyard Millet; 273), Panicum maximum (Guinea Grass; 233), Setaria verticillata (Hooked Bristlegrass; 2015) and Eragrostis cilianensis (Gray Lovegrass; 213) (Table 26.1).

In total, the 1093 species that are naturalised elsewhere belong to 132 families, and 515 genera, with Cyperus (29), Crassula (17), Oxalis (16), Erica and Pelargonium (both 15), Eragrostis, Moraea, Senecio (14), Gladiolus (12), Asparagus (11), Ipomoea (11) and Plectranthus (10) contributing the most naturalised plant species of South African origin. The naturalised flora of South African origin is dominated by some of the world's largest families that are also typically known as successful invaders, with Asteraceae, Poaceae and Fabaceae on top (Table 26.2). Also in global terms, these three families are the only ones with more than 1000 naturalised species; they contribute $10.2 \%, 9.8 \%$ and $9.0 \%$, respectively, to the naturalised flora of the world. However, whereas Poaceae and Fabaceae are over-represented among naturalised aliens, Asteraceae, which in absolute terms contributes the most species to the global naturalised flora, reaches a value that is expected from the family's global species richness (Pyšek et al. 2017).

In contrast to the general global pattern, there is a disproportionally large number of native South African grass species that have naturalised in other regions (165 species of Poaceae, i.e. $15.1 \%$ of the total number of South African grass species), while Asteraceae (the second most represented family) only contributes $59 \%$ of this number $(98 ; 8.9 \%)$. The top seven families on the list (including also Fabaceae, Cyperaceae, Iridaceae, Aizoaceae, and Lamiaceae) together account for more than half $(52 \%)$ of all South African species naturalised elsewhere. The dominance of Poaceae among naturalised South African species is even more remarkable if we look at the representation of this family among the top species in terms of number of GloNAF regions occupied-grass species make up 17 of the 35 species that occur in more than 100 regions (48.6\%); of other families, only Cyperaceae (3 species) and Cucurbitaceae (2 species) are represented more than once (Table 26.1). This highlights the prominent role of grasses as naturalised species globally (Canavan et al. 2019) and South Africa as an important source of them (Visser et al. 2016).

\subsection{Exchange of Naturalised Aliens Between South Africa and Other Continents: Donor-Recipient Dynamics}

South African native species differ in the frequency with which they have naturalised on other continents (Fig. 26.1), with Australia, Africa, and the Americas hosting the most species (Table 26.1). The global pattern of the contribution of South Africa to 


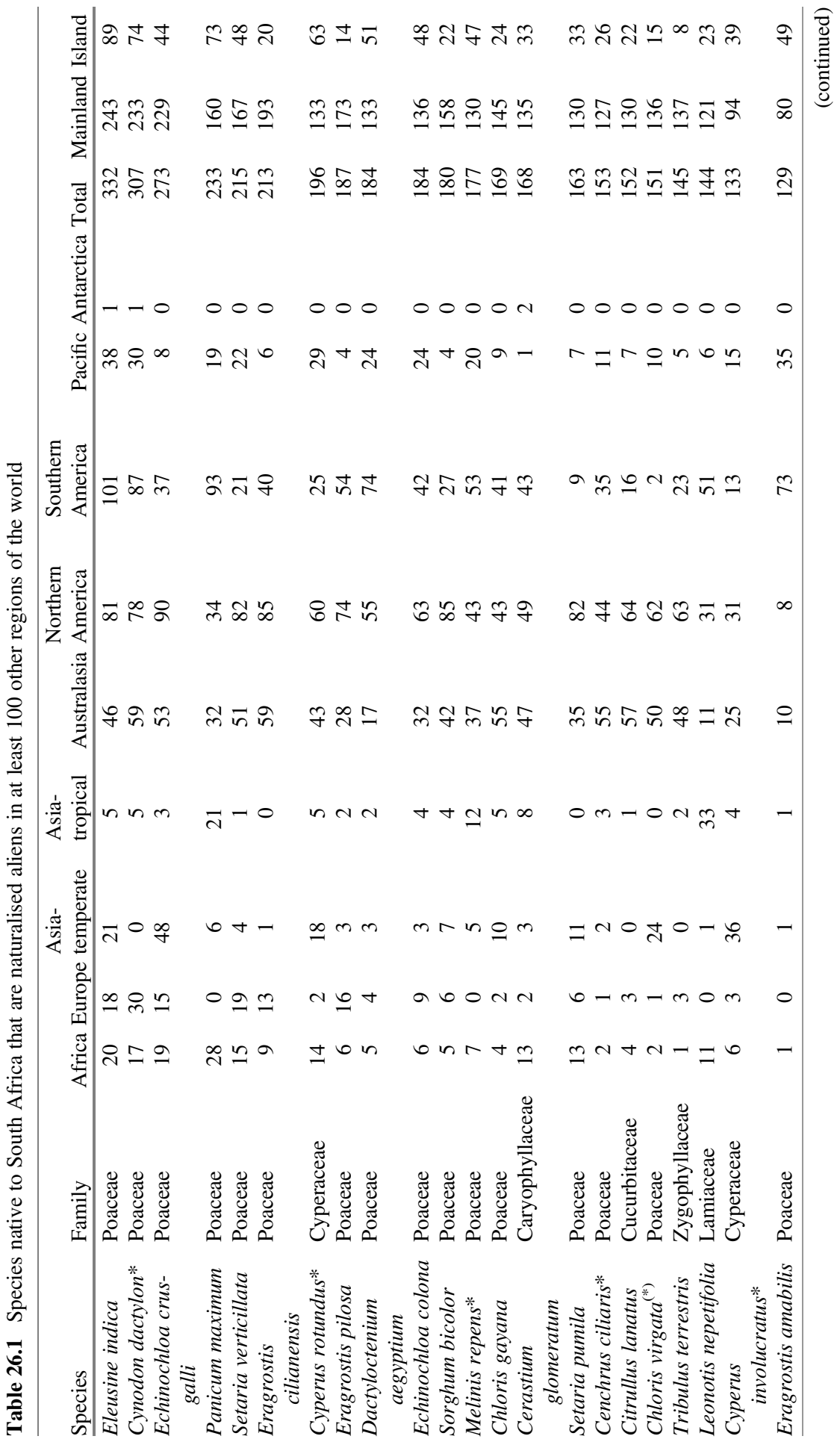




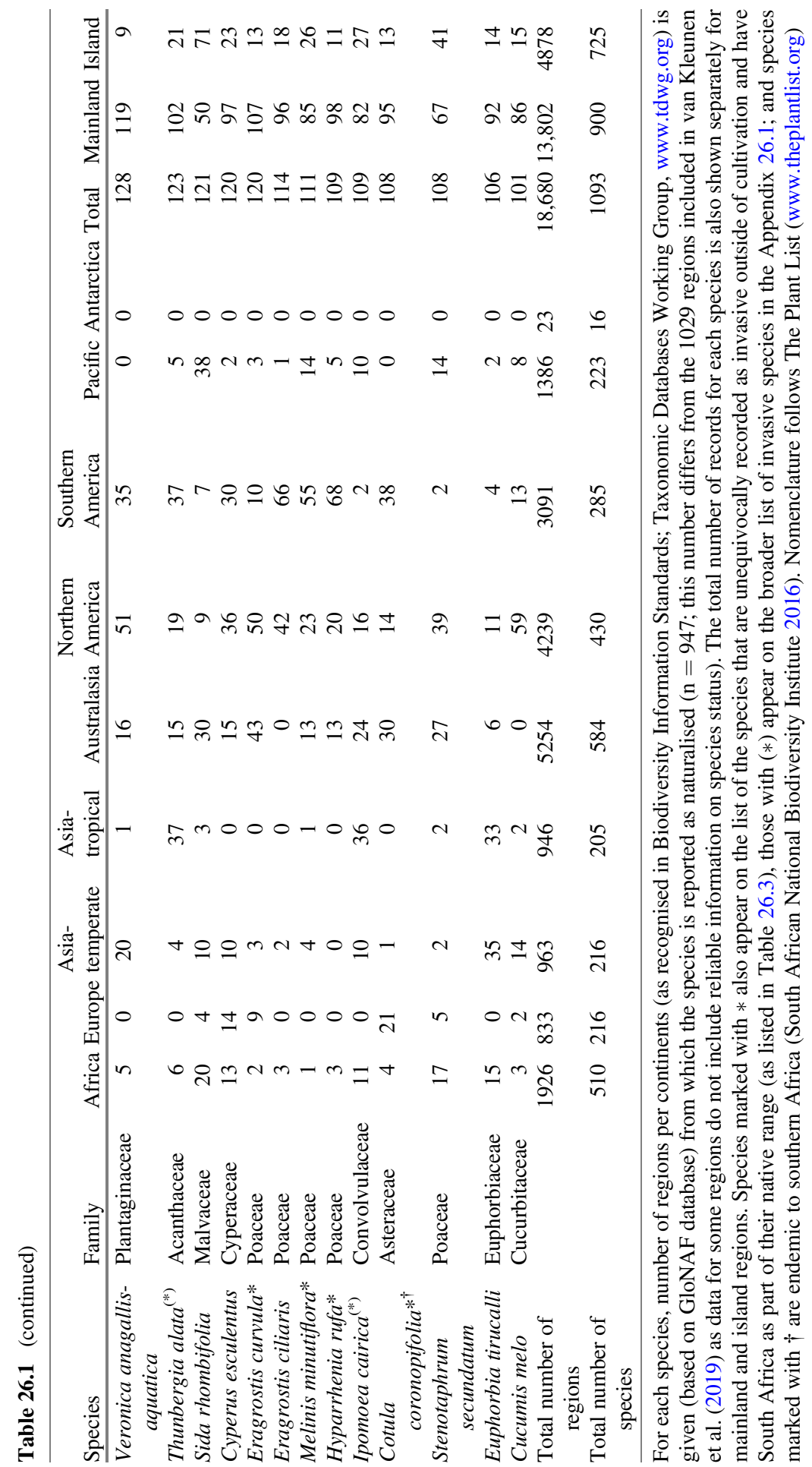




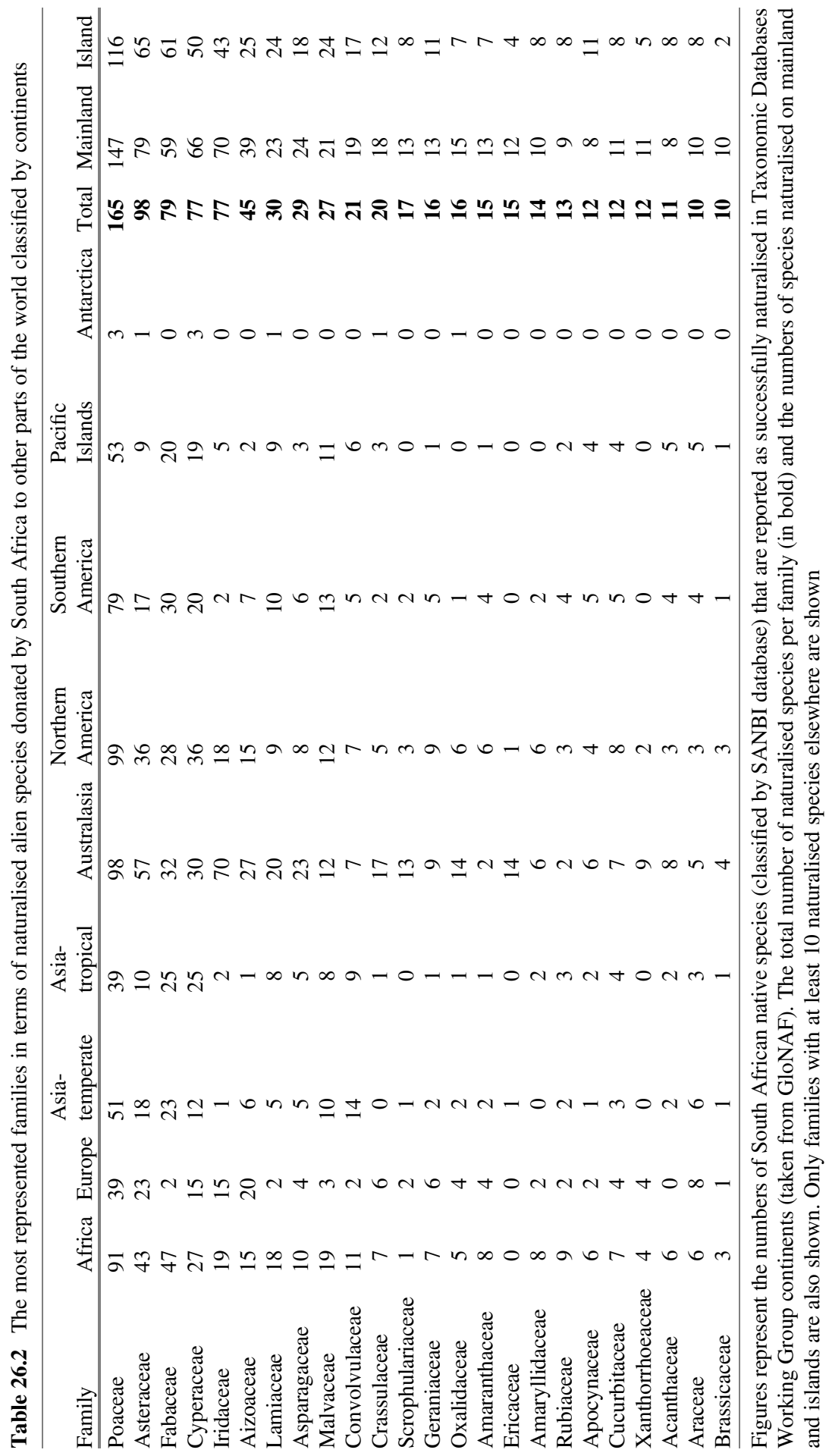




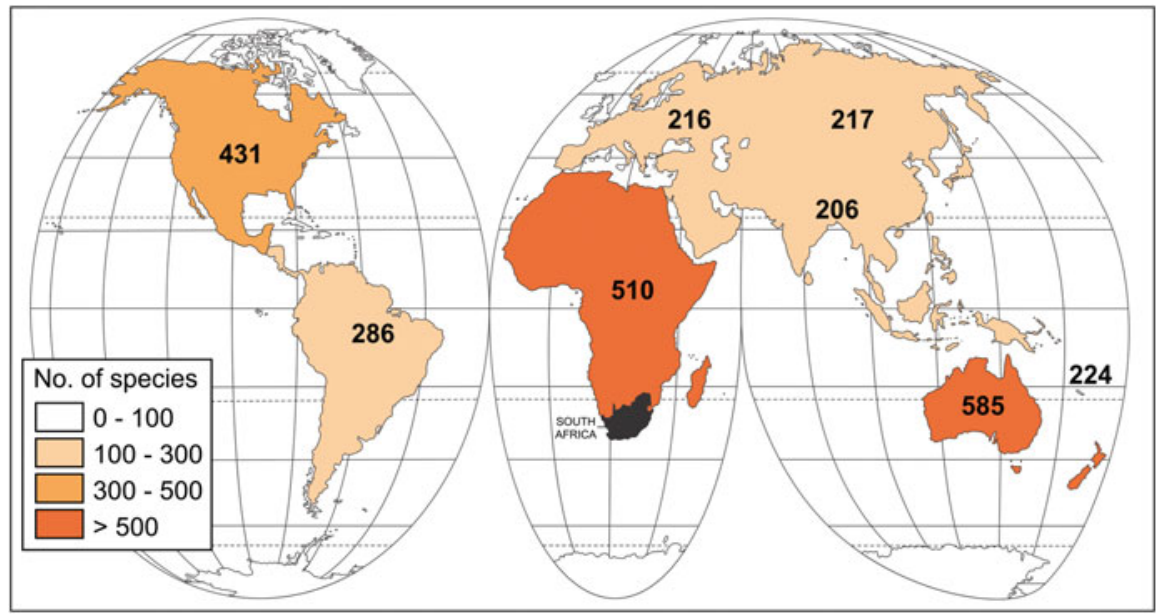

Fig. 26.1 South African native species naturalised on other continents. Areas richer in naturalised alien species that are native to South Africa are displayed in darker orange. The delimitation of continents follows that of Biodiversity Information Standards, used by Taxonomic Database Working Group (TDWG; www.tdwg.org)

overall naturalised floras reflects geographic distance, climatic suitability and cultural history. Thuiller et al. (2005) modelled a cumulative probability surface, comprising the sum of probability surfaces for 96 taxa, to show parts of the world that are most susceptible to invasion by South African plant species; such areas have Mediterranean-type climate and are located mainly in the southern hemisphere, most extensively in southern Australia, on the west coast of South America, and in the Northern Hemisphere, especially the Mediterranean Basin (Thuiller et al. 2005). Some of the areas to which South Africa has donated large numbers of naturalised alien species, based on the analysis in the present paper, are biodiversity hotspots, such as the California Floristic Province, Southwestern Australia and New Zealand. That the present results differ somewhat from the Thuiller et al. (2005) analysis can be explained by the different aims of the studies. Whereas Thuiller et al. (2005) focussed on invasive species, our goal was to present a global assessment of naturalised plant species that have South Africa as part of their native range.

The comparison of species exchange between South Africa and other continents reveals that for some continents the flows are rather balanced, with similar proportions of the total number of species received and donated (Fig. 26.2). This holds for the rest of Africa, North and South America, and tropical Asia. Since the total number of received naturalised species in South Africa (1139 according to GloNAF database; van Kleunen et al. 2019) and donated as naturalised to other continents (1093 species) is about the same, the proportional data shown in Fig. 26.2 correspond closely to absolute species numbers, which means that these continents 


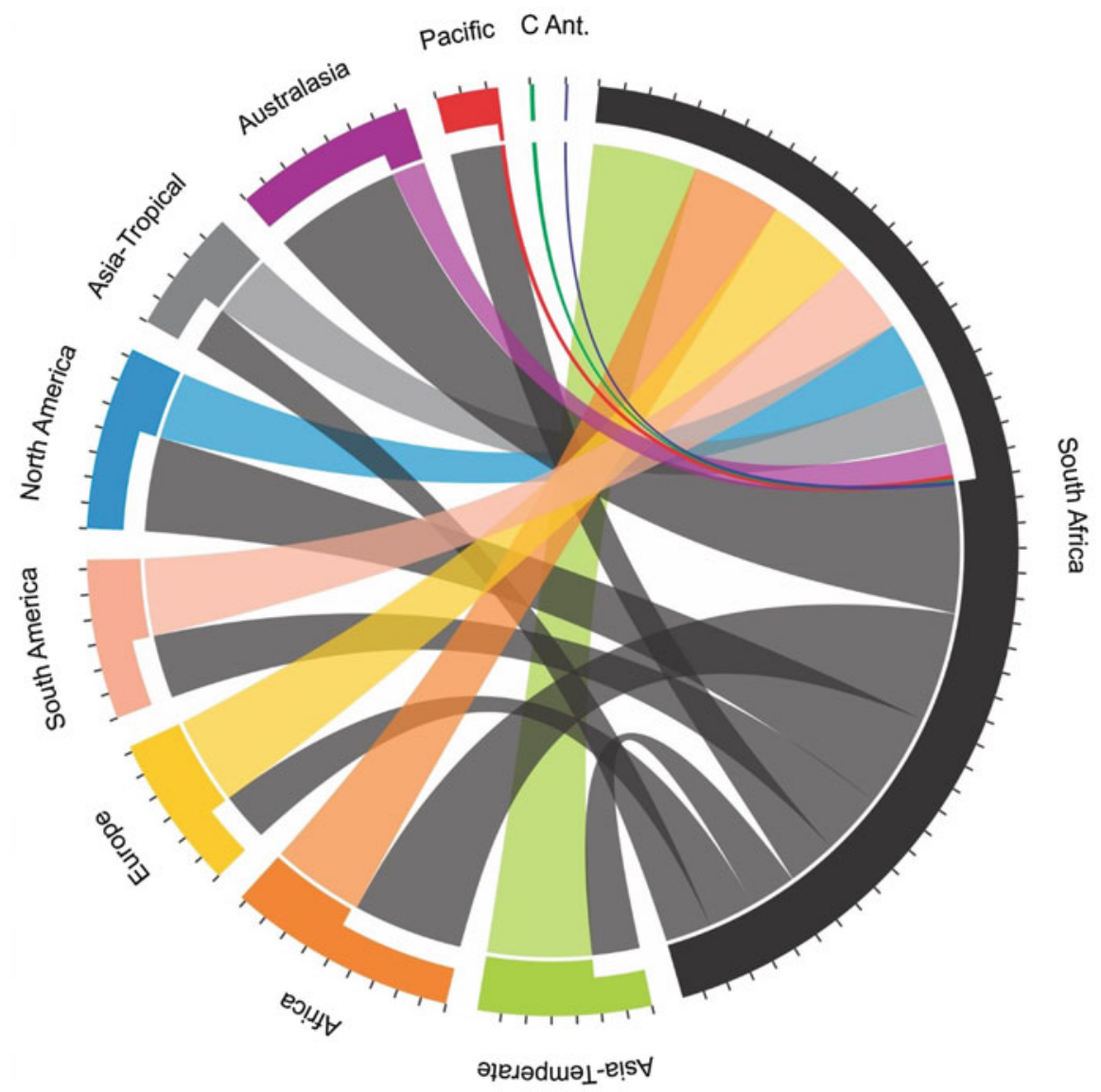

Fig. 26.2 Exchange of naturalised alien species between South Africa and other regions of the world. The delimitation of continents follows the Biodiversity Information Standards, used by Taxonomic Database Working Group (TDWG; www.tdwg.org), with Africa excluding South Africa, and Antarctica (Ant.) excluding the Prince Edward Islands. Black arrows represent native South African species naturalised on other continents, coloured arrows indicate the opposite flow (species native to other continents that have naturalised in South Africa). Each tick on the outside of the plot corresponds to 100 species and the thickness of arrows is proportional to the total number of species. The total number shown in the graph is larger than the real number because some species are native to multiple continents, and some South African species are naturalised in multiple continents. Continents are organised starting with the greatest donor region (Temperate Asia) and ending with the smallest donor (Ant: Antarctica). C stands for species only known from cultivation. Based on data from GloNAF (van Kleunen et al. 2015, 2019)

received about the same numbers of species from South Africa as they donated to this country. On the other hand, temperate Asia and Europe delivered markedly more naturalised species to South Africa than were received from South Africa, and Australasia harbours many more naturalised species of South African origin than it donated to South Africa (Fig. 26.2). 


\subsection{Comparison of South African Naturalised Flora with Neighbouring African Countries}

Comparing South Africa with neighbouring countries for which data are available reveals levels of invasion comparable to the $4.8 \%$ recorded for South Africa, despite generally lower numbers of naturalised alien species reported in Zimbabwe (238; 3.9\%-Maroyi 2012), Namibia (218; 4.8\%—Klaassen and Kwembeya 2013) and Botswana (170; 5.3\%-Setshogo 2005). There are likely several reasons that explain the lower absolute numbers of naturalised species: the smaller size of these countries (Zimbabwe 390,366 km² ; Botswana $578,233 \mathrm{~km}^{2}$ and Namibia $825,519 \mathrm{~km}^{2}$, compared to South Africa's $1,219,826 \mathrm{~km}^{2}$ ); the greater diversity of biomes, vegetation types, and environmental conditions found in South Africa (Fig. 1.2, van Wilgen et al. 2020, Chap. 1; Fig. 13.1, Wilson et al. 2020, Chap. 13); the much longer history of researchers focussing on invasions and recording naturalisation (Pyšek et al. 2008; Henderson and Wilson 2017); and probably also to the greater and longer history of international trade with South Africa. It is also likely that South Africa has acted as a bridge-head for plant invasions, with species originally being introduced to South Africa, and either spreading naturally or through human mediated-dispersal to neighbouring countries (Faulkner et al. 2017; see also Measey et al. 2020, Chap. 27).

\subsection{Plants Native to South Africa that Are Invasive Elsewhere in the World}

\subsubsection{The Big Picture}

Eighty plant taxa with native ranges including South Africa are clearly invasive (i.e. spreading over substantial distances from sites of introduction; Richardson et al. 2000b) in natural and semi-natural ecosystems in other parts of the world (Table 26.3). Australia is by far the region of the world with the highest number of invasive species of putative South African origin: $53(65 \%)$ of known invasive taxa are recorded as invasive in Australia. Europe (36 taxa) and North America (32 taxa) are the next most important target regions.

Adding candidate taxa to the list of invasives (i.e. including also those that have been variously listed in the literature as "invasive", "weedy", "widely naturalised" but for which clear evidence of invasiveness and precise geographic locations are lacking), resulted in an increase of the total number to 212 taxa (Appendix 26.1). Many of the taxa listed in the Appendix 26.1 (but not in Table 26.3) may well fulfil the criteria for "invasive", but we could not find strong supporting evidence for some borderline cases. Many others are recent introductions and are likely to become invasive in the near future. 
Table 26.3 List of 79 plant taxa native to South Africa that are unequivocally invasive (sensu Richardson et al. 2000b) in natural and semi-natural ecosystems outside of cultivation in other parts of the world

\begin{tabular}{|c|c|c|c|c|}
\hline Family & Species & $\begin{array}{l}\text { Endemic to } \\
\text { South Africa }\end{array}$ & $\begin{array}{l}\text { Regions } \\
\text { where } \\
\text { invasive }\end{array}$ & $\begin{array}{l}\text { Number of } \\
\text { GloNAF } \\
\text { regions }\end{array}$ \\
\hline \multirow[t]{3}{*}{ Aizoaceae } & Carpobrotus edulis \# & Yes & $5,6,14$ & 77 \\
\hline & $\begin{array}{l}\text { Mesembryanthemum } \\
\text { cordifolium (syn. Aptenia } \\
\text { cordifolia) }\end{array}$ & Yes & 5,7 & 66 \\
\hline & $\begin{array}{l}\text { Mesembryanthemum } \\
\text { crystallinum \# }\end{array}$ & No & $3,7,9,11$ & 94 \\
\hline \multirow[t]{2}{*}{ Apocynaceae } & $\begin{array}{l}\text { Gomphocarpus fruticosus (syn. } \\
\text { Asclepias fruticosa) }\end{array}$ & No & 5 & 82 \\
\hline & Gomphocarpus physocarpus & No & 3,5 & 77 \\
\hline Araceae & Zantedeschia aethiopica & No & $\begin{array}{l}3,4,5 \\
7,12,14\end{array}$ & 113 \\
\hline \multirow[t]{3}{*}{ Asparagaceae } & Asparagus aethiopicus & No & $3,4,7,11$ & 40 \\
\hline & Asparagus asparagoides \# & No & $3,5,7$ & 61 \\
\hline & Asparagus scandens & Yes & 3,4 & 12 \\
\hline Asphodelaceae & Trachyandra divaricata & Yes & 3 & 12 \\
\hline \multirow[t]{13}{*}{ Asteraceae } & $\begin{array}{l}\text { Arctotheca calendula (syn. } \\
\text { Arctotis tristis) \# }\end{array}$ & No & $3,5,7$ & 85 \\
\hline & Chrysanthemoides monilifera \# & No & 3,14 & 42 \\
\hline & Cotula coronopifolia & Yes & 5,7 & 119 \\
\hline & $\begin{array}{l}\text { Delairea odorata (syn. Senecio } \\
\text { mikanioides) \# }\end{array}$ & No & 5,7 & 70 \\
\hline & Gazania linearis & Yes & $3,4,5,7$ & 31 \\
\hline & Gazania rigens & No & $3,5,7,9,14$ & 31 \\
\hline & Senecio angulatus & Yes & $2,3,4,5$ & 31 \\
\hline & Senecio elegans & Yes & $3,5,7$ & 25 \\
\hline & Senecio glastifolius & Yes & 3,4 & 10 \\
\hline & Senecio inaequidens & Yes & 5,14 & 61 \\
\hline & Senecio madagascariensis & No & $2,3,9,11$ & 40 \\
\hline & Senecio pterophorus & Yes & 3,5 & 10 \\
\hline & Vellereophyton dealbatum & Yes & 3,4 & 27 \\
\hline Bignoniaceae & Podranea ricasoliana & Yes & 12 & 29 \\
\hline Cucurbitaceae & Сucumis myriocarpus & No & 5 & 62 \\
\hline \multirow[t]{3}{*}{ Cyperaceae } & Cyperus congestus & No & 5 & 35 \\
\hline & Cyperus involucratus & No & 5 & 148 \\
\hline & Cyperus rotundus & No & $>>$ & 236 \\
\hline \multirow[t]{6}{*}{ Fabaceae } & Crotalaria lanceolata & No & 10 & 47 \\
\hline & Dichrostachys cinerea \# & No & $3,7,12,13$ & 9 \\
\hline & Dipogon lignosus & Yes & 3 & 26 \\
\hline & Psoralea pinnata & No & $4,5,7$ & 17 \\
\hline & Vachellia karroo & No & 3,5 & 1 \\
\hline & Vachellia nilotica & No & 3,11 & 17 \\
\hline Geraniaceae & Pelargonium capitatum & Yes & 3,5 & 21 \\
\hline Hyacinthaceae & Lachenalia reflexa & Yes & 3 & 4 \\
\hline Hydrocharitaceae & Lagarosiphon major & No & 5 & 18 \\
\hline \multirow[t]{2}{*}{ Iridaceae } & Chasmanthe aethiopica & Yes & 5,11 & 7 \\
\hline & Chasmanthe floribunda & Yes & $3,5,7$ & 28 \\
\hline
\end{tabular}


Table 26.3 (continued)

\begin{tabular}{|c|c|c|c|c|}
\hline Family & Species & $\begin{array}{l}\text { Endemic to } \\
\text { South Africa }\end{array}$ & $\begin{array}{l}\text { Regions } \\
\text { where } \\
\text { invasive }\end{array}$ & $\begin{array}{l}\text { Number of } \\
\text { GloNAF } \\
\text { regions }\end{array}$ \\
\hline & Crocosmia $\times$ crocosmiiflora & Yes & 5,7 & 112 \\
\hline & Ferraria crispa & Yes & 5,7 & 25 \\
\hline & $\begin{array}{l}\text { Freesia leichtlinii subsp. alba } \\
\quad(=\text { Freesia alba })\end{array}$ & No & 5,7 & 9 \\
\hline & Gladiolus caryophyllaceus & Yes & 3 & 9 \\
\hline & Romulea rosea var. australis & Yes & $3,4,7$ & 38 \\
\hline & Sparaxis bulbifera & Yes & 3,5 & 20 \\
\hline & Watsonia meriana & Yes & $3,4,7$ & 23 \\
\hline \multirow[t]{2}{*}{ Juncaceae } & Juncus acutus & No & 3 & 52 \\
\hline & Juncus effusus & No & 3,12 & 46 \\
\hline Lythraceae & Trapa natans & No & 7 & 12 \\
\hline Ochnaceae & Ochna serrulata & Yes & 3,4 & 14 \\
\hline Oleaceae & $\begin{array}{l}\text { Olea europaea subsp. cuspidata } \\
\ldots\end{array}$ & No & 3 & 18 \\
\hline Orchidaceae & $\begin{array}{l}\text { Disa bracteata }(=\text { Monadenia } \\
\quad \text { bracteata })\end{array}$ & Yes & 3 & 18 \\
\hline \multirow[t]{3}{*}{ Oxalidaceae } & Oxalis glabra & Yes & 3 & 11 \\
\hline & Oxalis pes-caprae & Yes & $\begin{array}{c}3,4,5 \\
7,10 \\
13\end{array}$ & 110 \\
\hline & Oxalis purpurea & Yes & 5 & 53 \\
\hline \multirow[t]{19}{*}{ Poaceae } & Andropogon gayanus \# & No & 3 & 17 \\
\hline & $\begin{array}{l}\text { Cenchrus ciliaris }(= \\
\text { Pennisetum ciliare }) \#\end{array}$ & No & $3,7,11$ & 224 \\
\hline & Cynodon dactylon & No & 11,14 & 355 \\
\hline & Digitaria eriantha & No & 11 & 77 \\
\hline & Ehrharta calycina & No & $3,5,7$ & 43 \\
\hline & Ehrharta erecta & Yes & $\begin{array}{l}3,4,5, \\
\quad 7,10,11\end{array}$ & 39 \\
\hline & Eragrostis curvula & No & 3,5 & 129 \\
\hline & Eragrostis lehmanniana & Yes & 3,7 & 19 \\
\hline & Eragrostis plana & No & 9 & 10 \\
\hline & Hyparrhenia hirta \# & No & 3,11 & 48 \\
\hline & Hyparrhenia rufa \# & No & $\begin{array}{l}3,7,8, \\
\quad 9,10,11\end{array}$ & 134 \\
\hline & Imperata cylindrica & No & $>>9,10,11$ & 52 \\
\hline & $\begin{array}{l}\text { Megathyrsus maximus (syn. } \\
\text { Panicum maximum) }\end{array}$ & No & 7,11 & 305 \\
\hline & Melinis minutiflora \# & No & $7,9,11,14$ & 139 \\
\hline & Melinis repens & No & $3,7,9,10$ & 204 \\
\hline & Panicum repens & No & $3,8,10$ & 75 \\
\hline & Pennisetum macrourum & No & 3,4 & 13 \\
\hline & Sporobolus natalensis & No & 3 & 14 \\
\hline & Sporobolus pyramidalis & No & 3 & 52 \\
\hline
\end{tabular}


Table 26.3 (continued)

\begin{tabular}{llllc}
\hline Family & Species & $\begin{array}{l}\text { Endemic to } \\
\text { South Africa }\end{array}$ & $\begin{array}{l}\text { Regions } \\
\text { where } \\
\text { invasive }\end{array}$ & $\begin{array}{l}\text { Number of } \\
\text { GloNAF } \\
\text { regions }\end{array}$ \\
\hline Polygalaceae & Polygala myrtifolia & Yes & 5 & 28 \\
& Rumex sagittatus & No & 3,4 & 9 \\
Scrophulariaceae & Zaluzianskya divaricata & Yes & 3 & 24 \\
Solanaceae & Lycium ferocissimum & No & 3,4 & 70 \\
& Solanum linnaeanum & No & $3,4,11$ & 47 \\
\hline
\end{tabular}

Taxa marked \# have major ecosystem-level impacts and may be considered "transformers" (sensu Richardson et al. 2000b). Thirty-one species are considered endemic to South Africa based on their coding as "Indigenous; Endemic" on the web site www.newposa.org (South African National Biodiversity Institute 2016). A list of all other widely naturalised taxa with native ranges in South Africa, including those that do not clearly fulfil the criteria for being classified as "invasive", appears in the Appendix 26.1. Regions are those defined by Richardson and Rejmánek (2011): (1) Africa (southern); (2) Africa (rest; north of $20^{\circ} \mathrm{S}$ ); (3) Australia; (4) New Zealand; (5) Europe (including Russia west of the Ural Mountains); (6) Middle East (south-western Asia); (7) North America; (8) Central America; (9) South America; (10) Asia (including China, India, Southeast Asia, Hong Kong, Singapore, and Russia east of the Ural Mountains); (11) Pacific Islands (including French Polynesia, Hawaii, Japan and the Bonin [Ogasawara] Islands; Kiribati and Micronesia); (12) Indian Ocean Islands and Madagascar (including the Mascarene Islands and Sri Lanka); (13) Caribbean Islands; (14) Atlantic Islands (Azores, Bermuda, Canary Islands, Falkland Islands; Madeira, Outer Hebrides, St Helena and Tristan da Cunha); and (15) Indonesia; $>>$ invasive in numerous regions. Many taxa listed here are present in more regions than are listed here-listed regions are those with unequivocal evidence of invasiveness. See the Appendix 26.1 for species author's names

\subsubsection{Taxonomic Patterns}

South African taxa that are clearly invasive belong to 25 families, with four families (Poaceae-19 taxa; Asteraceae-14; Iridaceae-9; and Fabaceae-5) together contributing 58\% of taxa to the list (Table 26.3). As mentioned previously, several South African native plants qualify as textbook examples of the dramatic impacts that plant invasions can cause. No global review of the impacts of plant invasions would be complete without coverage of the invasion ecology of Asparagus asparagoides (Bridal Creeper-Fig. 26.3d), Carpobrotus edulis, Chrysanthemoides monilifera (Fig. 26.3h), and the suite of African grasses that have transformed invaded grasslands in many parts of the world (Andropogon gayanus-Fig. 26.3b, Cenchrus ciliaris-Fig. 26.3f, and others). In total, 13 of the 79 taxa (16\%) listed in Table 26.3 can be considered to be transformers (sensu Richardson et al. 2000b), i.e. species that have a major impact on the structure and functioning of ecosystems in other parts of the world.

Of particular interest and importance is South Africa's (or perhaps more correctly Africa's) contribution to the "A-list" of invasive grasses around the world. The Poaceae taxa in Table 26.3 are key contributors to regime shifts driven by invasive species in many parts of the world (D'Antonio and Vitousek 1992; Brooks et al. 2004; Gaertner et al. 2014). Visser et al. (2016) explored the role of South Africa as a 

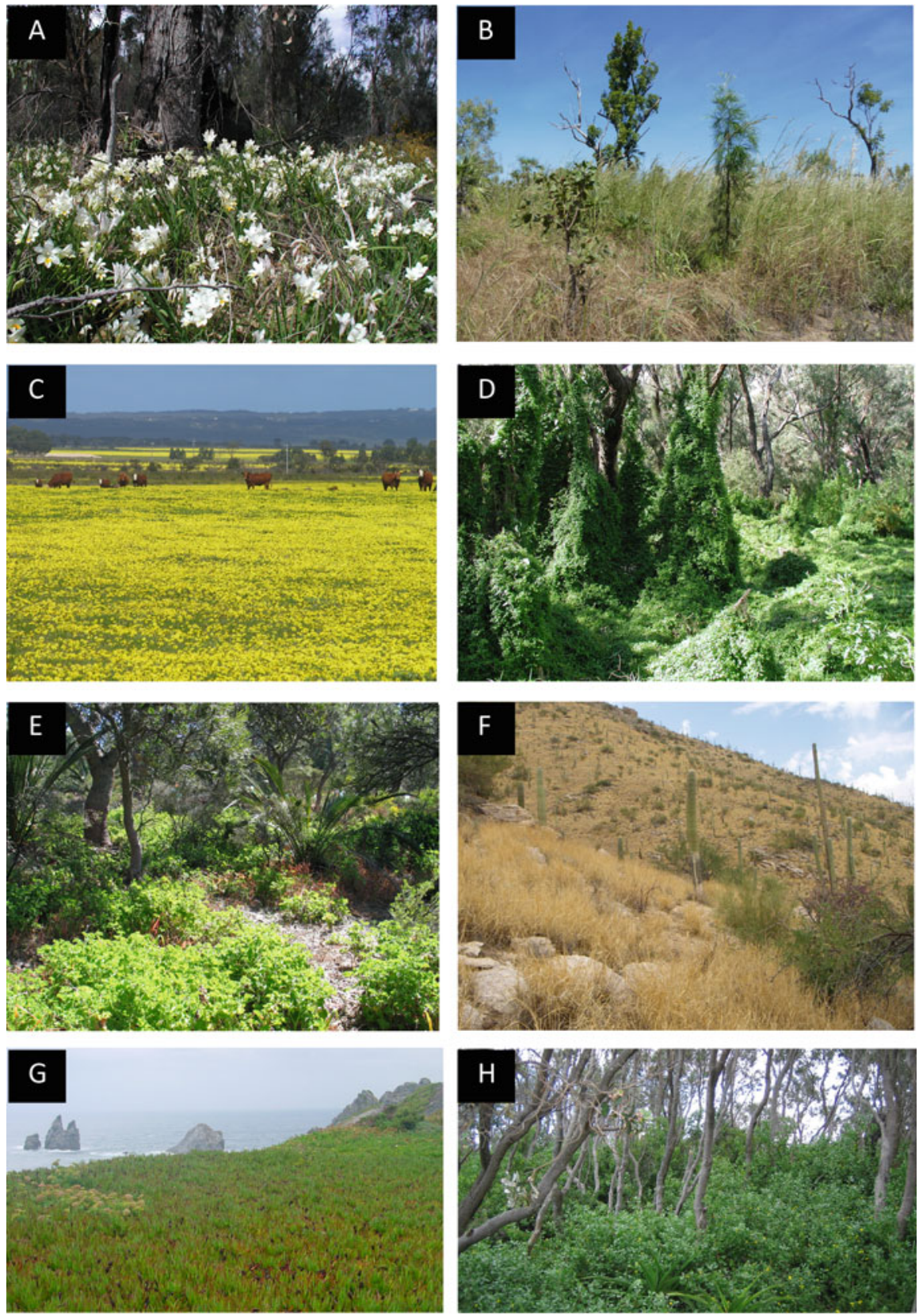

Fig. 26.3 Examples of South African plant species that are invasive (sensu Richardson et al. 2000b) in natural or semi-natural ecosystems in other parts of the world. (a) Freesia leichtlinii subsp. alba (Iridaceae; White Freesia) in Western Australian kwongan; (b) Andropogon gayanus (Poaceae; Gamba Grass) in eucalypt savanna, Northern Territory, Australia; (c) Arctotheca calendula (Asteraceae; Cape Weed) in Western Australia; (d) Asparagus asparagoides (Asparagoideae; 
major donor of invasive grasses. They suggested that selective pressures over evolutionary time scales, in particular the regular occurrence of intense fires and strong grazing pressure from a diverse large mammal fauna, resulted in Africa operating as a "factory" for invasive grasses with traits and syndromes to cope with fire, grazing, and disturbance. Around a tenth of all grasses have naturalised somewhere in the world, but only $8 \%$ of these species have naturalised in South Africa (i.e. $\sim 0.8 \%$ of Poaceae). By contrast, around $16 \%$ of all grasses native to South Africa have naturalised somewhere else in the world (i.e. 20-fold greater than the global proportion).

While South Africa might be a "factory" for invasive grasses, it is clearly also a major "hotspot" of alien tree invasions (see Box 3.1 in Richardson et al. 2020). About a third of the world's invasive alien tree species are invasive in South Africa (Rejmánek and Richardson 2013), but only 4\% of the global set of invasive tree species have South Africa as part of their native range. Although many reasons for South Africa's susceptibility to alien tree invasions have been proposed (e.g. Richardson and Cowling 1992; Rundel et al. 2014), more research is needed to resolve this anomaly.

South African Asteraceae also feature very prominently in the international literature on plant invasions, thanks mainly to the successes of Senecio species as major invaders around the world. Indeed, this genus has been proposed as an excellent model system to tackle open questions in invasion ecology (Kueffer et al. 2013). Work on South African Senecio species has shed light on the role of adaptive evolution (Dormontt et al. 2014), admixture and hybridisation (Vilatersana et al. 2018), phenotypic plasticity (Bossdorf et al. 2008), and ploidy level (Lafuma et al. 2003) in invasions.

Less prominent in the international invasion literature, but likely to feature more in the future, are South African taxa in the Iridaceae family. South Africa is home to more than half of the approximately 1800 species of Iridaceae, with 27 genera and over 700 species in the Cape Floristic Region alone (Manning and Goldblatt 2012). Many iris species from the Cape Floristic Region have been widely planted as garden subjects in many parts of the world, and many are known to be naturalised or "weedy" (van Kleunen et al. 2007). The nine taxa listed in Table 26.3 probably represent "the tip of the iceberg" as many other taxa (especially in Australia) seem to be on the verge of becoming invasive. Several studies have explored the determinants of naturalisation success in South African Iridaceae. It has been shown that, compared to non-naturalised South African Iridaceae, naturalised species tend to

Fig. 26.3 (continued) Bridal Creeper) in Western Australia; (e) Pelargonium capitatum (Geraniaceae; Rose-scented Pelargonium) in Western Australian kwongan; (f) Cenchrus ciliaris (Poaceae; Buffel Grass) at Coronado National Forest, New Mexico Arizona, USA; (g) Carpobrotus edulis on Porquerolles, Hyères Archipelago, France; (h) Chrysanthemoides monilifera (Asteraceae; Bitou Bush) in Victoria, Australia. Photographs courtesy of-D. M. Richardson (a, b, c, e); P. O. Downey (d, h); J. L. Betancourt (f), A. Traveset (g) 
occur in South Africa at lower altitudes, are tall, and have usually multiple infraspecific taxa (van Kleunen et al. 2007). Moreover, it was shown that many of the naturalised Iridaceae are capable of autonomous seed set (van Kleunen et al. 2008), and have fast and profuse seedling emergence (van Kleunen and Johnson 2007). There is nevertheless scope for much more research on the invasion ecology of this group. The aspects that are ripe for further work include the role of fossorial mammals in the evolution of reproductive strategies in different groups, and the implications for invasion success in areas that lack fossorial mammals (such as eastern Australia). Brachycerus weevils (Coleoptera: Curculionoidea), a radiation of several hundred species, mostly in the Cape Floristic Region (Hickman et al. 2017), also exert major herbivory pressure on above- and below-ground parts of irids in the Cape Floristic Region. How escape from such herbivory pressure mediates survival, reproduction and spread in regions like Australia also merits research.

The South African orchid Disa bracteata (South African Weed Orchid) is one of only a handful of species in the family Orchidaceae globally that is clearly invasive (in Australia). Orchidaceae is typically considered the "poster-child non-invasive" plant family (Pyšek et al. 2017), largely because of their highly specialised pollination systems, epiphytism, but also because of their apparent dependence on specialised mycorrhizal associations (Richardson et al. 2000a). New records of invasive orchids are thus interesting and merit further research.

Many South African plant taxa, besides those listed in Tables 26.1 and 26.3, are widely planted around the world as ornamentals. Prominent families among the South African "diaspora flora" are Asparagaceae, Asteraceae, Aizoaceae, Ericaceae, Geraniaceae, Iridaceae, Orchidaceae and Proteaceae. Taxa in these families have different residence times - as popular garden subjects they were introduced at various times, and have enjoyed different levels of dissemination around the world. The natural experiment of testing the capacity of South African plants to naturalise and invade outside of their native ranges is thus still underway. Some widely-planted species that are already naturalised will clearly move along the introduction-naturalisation-invasion continuum to become invasive. Some surprises are likely in coming decades, but it is unlikely that patterns revealed in this chapter will change substantially. Australia stands out as the region most affected by invasive South African species. A detailed assessment of the introduction status and the dimensions of the invasion debt (sensu Rouget et al. 2016) for South Africa plants in Australia would be useful to develop early warning lists and management options. 


\subsection{Naturalised Distributions and Invasive Status as Different Dimensions of Success}

The approach we adopted in the present chapter-to evaluate the contribution of the South African native flora to global plant naturalisation and invasions separatelyallows for making some interesting comparisons. As discussed in detail in the recent account on the alien floras of the world (Pyšek et al. 2017), there are differences in how the definitions of "naturalised" and "invasive" are applied in different regions. Nevertheless, the overlap between species that are naturalised in many regions and those that are unequivocally invasive outside of cultivation is fairly small-among the 35 native South African taxa that were reported as naturalised from more than 100 regions of the world (Table 26.1), only $12(34.2 \%)$ are invasive, nine of them appearing on the list where there is strong evidence of invasiveness [Buffel Grass (Cenchrus ciliaris), Brass Button (Cotula coronopifolia), Bermuda Grass (Cynodon dactylon), Common Nut Sedge (Cyperus involucratus), Purple Nutsedge (Cyperus rotundus), Weeping lovegrass (Eragrostis curvula), Jaragua Grass (Hyparrhenia rufa), Molasses Grass (Melinis minutiflora), Natal grass (Melinis repens)], and three on the broader list of invasives [Feather Fingergrass (Chloris virgata), Black-eyed Susan Vine (Thunbergia alata), Cairo Morning Glory (Ipomoea cairica)]. These figures indicate that to be widely distributed does not always mean to be a strong invader, and that taxa that are extremely successful as invaders in some regions only succeed in specific environmental and geographic settings and many of them do not qualify as widespread alien plants. We suspect that many of the most widespread naturalised species recorded here are weeds of agricultural or disturbed environments [e.g. Indian Goosegrass (Eleusine indica), Muskmelon (Cucumis melo), and Great Millet (Sorghum bicolor); those without asterisks in Table 26.1]. They might have important negative impacts, and can be considered as invasive in a broad sense, but they are do not thrive outside of cultivation. This does not, however, mean that the impacts should not be recorded nor that they will require management to reduce negative impacts (e.g. see Nkuna et al. 2018 for grasses).

Acknowledgements PP and JP were supported by EXPRO grant no. 19-28807X (Czech Science Foundation) and long-term research development project RVO 67985939 (The Czech Academy of Sciences). DMR and JRW acknowledge support from the DSI-NRF Centre of Excellence for Invasion Biology and the National Research Foundation of South Africa (grant 85417). FE received funding by the BiodivERsA-Belmont Forum Project "Alien Scenarios" (FWF project no I 4011B32). MvK and MW received funding of the German Research Foundation DFG (MvK: project number 264740629; MW: FZT 118). The South African Department of Environment, Forestry, and Fisheries (DEFF) are thanked for funding the South African National Biodiversity Institute noting that this publication does not necessarily represent the views or opinions of DEFF or its employees. We thank many colleagues from around the world who answered diverse queries about the status of South Africa native plants in their regions and/or taxa about which they have specialist knowledge. 


\section{Appendix 26.1: List of 212 Plant Taxa Native to South Africa that Are Listed as Invasive in the Literature}

\begin{tabular}{|c|c|c|}
\hline Family & Species & Status \\
\hline Acanthaceae & Thunbergia alata Bojer ex Sims & W \\
\hline \multirow{19}{*}{ Aizoaceae } & Aizoon pubescens Eckl. and Zeyh. (syn. Galenia pubescens) & $\mathrm{W}$ \\
\hline & Carpobrotus acinaciformis (L.) L. Bolus & $\mathrm{W}$ \\
\hline & Carpobrotus chilensis (Molina) N.E. Br & $\mathrm{W}$ \\
\hline & Carpobrotus edulis (L.) N.E. $\mathrm{Br}$ & $\mathrm{X}$ \\
\hline & Conicosia pugioniformis (L.) N.E. Br. & $\mathrm{W}$ \\
\hline & Disphyma crassifolium (L.) L. Bolus & $\mathrm{W}$ \\
\hline & Drosanthemum candens (Haw.) Schwantes & $\mathrm{W}$ \\
\hline & Drosanthemum floribundum (Haw.) Schwantes & $\mathrm{W}$ \\
\hline & Lampranthus falciformis (Haw.) N.E. Br. & $\mathrm{W}$ \\
\hline & Lampranthus spectabilis N.E.Br. & $\mathrm{W}$ \\
\hline & Malephora crocea (Jacq.) Schwantes & $\mathrm{W}$ \\
\hline & Malephora lutea (Haw.) Schwantes & $\mathrm{W}$ \\
\hline & Malephora purpureo-crocea (Haw.) Schwantes & $\mathrm{W}$ \\
\hline & Mesembryanthemum cordifolium L.f. (syn. Aptenia cordifolia) & $\mathrm{X}$ \\
\hline & Mesembryanthemum crystallinum $\mathrm{L}$. & $\mathrm{X}$ \\
\hline & Mesembryanthemum nodiflorum $\mathrm{L}$. & $\mathrm{W}$ \\
\hline & Mesembryanthemum guerichianum $\mathrm{Pax}$ & $\mathrm{W}$ \\
\hline & Ruschia caroli (L. Bolus) Schwantes & $\mathrm{W}$ \\
\hline & Ruschia tumidula (Haw.) Schwantes & $\mathrm{W}$ \\
\hline Aloaceae & Aloe striata Haw. & $\mathrm{W}$ \\
\hline \multirow[t]{2}{*}{ Amaryllidaceae } & Amaryllis belladonna $\mathrm{L}$. & $\mathrm{W}$ \\
\hline & Nerine filifolia Baker & $\mathrm{W}$ \\
\hline \multirow[t]{3}{*}{ Apocynaceae } & Cryptostegia grandiflora $\mathrm{R} . \mathrm{Br}$. & $\mathrm{X}$ \\
\hline & Gomphocarpus fruticosus (L.) W.T. Aiton (syn. Asclepias fruticosa) & $\mathrm{X}$ \\
\hline & Gomphocarpus physocarpus E. Mey. & $\mathrm{X}$ \\
\hline Aponogetoceae & Aponogeton distachyos L.f. & $\mathrm{W}$ \\
\hline Araceae & Zantedeschia aethiopica (L.) Spreng. & $\mathrm{X}$ \\
\hline \multirow[t]{6}{*}{ Asparagaceae } & Asparagus aethiopicus $\mathrm{L}$. & $\mathrm{X}$ \\
\hline & Asparagus asparagoides (L.) Druce & $\mathrm{X}$ \\
\hline & Asparagus densiflorus (Kunth) Jessop & $\mathrm{W}$ \\
\hline & Asparagus scandens Thunb. & $\mathrm{X}$ \\
\hline & Asparagus setaceus (Kunth) Jessop & $\mathrm{W}$ \\
\hline & Elide asparagoides (L.) Kerguélen & $\mathrm{W}$ \\
\hline \multirow[t]{4}{*}{ Asphodelaceae } & Aloe arborescens Miller & $\mathrm{W}$ \\
\hline & Aloe maculata All. & $\mathrm{W}$ \\
\hline & Kniphofia uvaria $\mathrm{L}$. & $\mathrm{W}$ \\
\hline & Trachyandra divaricata (Jacq.) Kunth & $\mathrm{X}$ \\
\hline \multirow[t]{9}{*}{ Asteraceae } & Berkheya rigida (Thunb.) Ewart, Jean White and B. Rees. & $\mathrm{W}$ \\
\hline & Arctotheca calendula (L.) Levyns (syn. Arctotis tristis) & $\mathrm{X}$ \\
\hline & Arctotheca populifolia (P.J. Bergius) Norl. & $\mathrm{W}$ \\
\hline & Arctotis stoechadifolia P.J. Bergius & $\mathrm{W}$ \\
\hline & Chrysanthemoides monilifera (L.) Norlindh & $\mathrm{X}$ \\
\hline & Conyza ivifolia (L.) Less. & $\mathrm{W}$ \\
\hline & Cotula coronopifolia $\mathrm{L}$. & $\mathrm{X}$ \\
\hline & Cotula turbinata $\mathrm{L}$. & $\mathrm{W}$ \\
\hline & Delairea odorata Lem. & $\mathrm{X}$ \\
\hline
\end{tabular}




\begin{tabular}{|c|c|c|}
\hline Family & Species & Status \\
\hline & Euryops abrotnifolius (L.) DC. & $\mathrm{W}$ \\
\hline & $\begin{array}{l}\text { Euryops chrysanthemoides (DC.) B. Nord (syn. Steirodiscus } \\
\text { chrysanthemoides) }\end{array}$ & $\mathrm{W}$ \\
\hline & Euryops multifidus (Thunb.) DC. & $\mathrm{W}$ \\
\hline & Gazania linearis (Thunb.) Druce & $\mathrm{X}$ \\
\hline & Gazania rigens (L.) Gaertn. & $\mathrm{X}$ \\
\hline & Gorteria personata $\mathrm{L}$. & $\mathrm{W}$ \\
\hline & Helichrysum foetidum (L.) Cass. & $\mathrm{W}$ \\
\hline & Helichrysum petiolare Hilliard and B.L. Burtt & $\mathrm{W}$ \\
\hline & Helichrysum petiolare Hilliard and Burtt & $\mathrm{W}$ \\
\hline & Plecostachys serpyllifolia (Berg.) Hilliard and B.L. Burtt & $\mathrm{W}$ \\
\hline & Pseudognaphalium undulatum (L.) Hilliard and B.L. Burtt & $\mathrm{W}$ \\
\hline & Senecio angulatus L. fil. & $\mathrm{X}$ \\
\hline & Senecio elegans $\mathrm{L}$. & $X$ \\
\hline & Senecio glastifolius L.f & $X$ \\
\hline & Senecio inaequidens DC & $\mathrm{X}$ \\
\hline & Senecio macroglossus DC. & $\mathrm{W}$ \\
\hline & Senecio madagascariensis Poir. & $\mathrm{X}$ \\
\hline & Senecio mikanioides Otto ex Walpers & $\mathrm{X}$ \\
\hline & Senecio pterophorus DC. & $\mathrm{X}$ \\
\hline & Vellereophyton dealbatum (Thunb.) Hilliard and Burtt. & $\mathrm{X}$ \\
\hline Bignoniaceae & Podranea ricasoliana (Tanfani) Sprague & $\mathrm{X}$ \\
\hline Brassicaceae & Heliophila pusilla L.f. & $\mathrm{W}$ \\
\hline \multirow[t]{4}{*}{ Campanulaceae } & Grammatotheca bergiana (Cham.) C. Presl & $\mathrm{W}$ \\
\hline & Lobelia erinus $\mathrm{L}$. & $\mathrm{W}$ \\
\hline & Lobelia pinifolia $\mathrm{L}$ & $\mathrm{W}$ \\
\hline & Wahlenbergia capensis (L.) A. DC. & $\mathrm{W}$ \\
\hline Cannabaceae & Trema orientalis (L.) Blume & $\mathrm{W}$ \\
\hline Ceratophyllaceae & Ceratophyllum demersum $\mathrm{L}$. & $\mathrm{W}$ \\
\hline Colchiaceae & Baeometra uniflora (Jacq.) G.J. Lewis & $\mathrm{W}$ \\
\hline Convolvulaceae & Ipomoea cairica $(\mathrm{L}$.$) Sweet$ & $\mathrm{W}$ \\
\hline \multirow[t]{5}{*}{ Crassulaceae } & Cotyledon orbiculata $\mathrm{L}$. & $\mathrm{W}$ \\
\hline & Crassula multicava Lemaire & $\mathrm{W}$ \\
\hline & Crassula muscosa $\mathrm{L}$. & $\mathrm{W}$ \\
\hline & Crassula sarmentosa Harv. var. sarmentosa & $\mathrm{W}$ \\
\hline & Tillaea campestris (Eckl. and Zeyh.) Brullo, Giusso and Siracusa & $\mathrm{W}$ \\
\hline Cucurbitaceae & Cucumis myriocarpus Naudin & $\mathrm{X}$ \\
\hline \multirow[t]{6}{*}{ Cyperaceae } & Bulbostylis striatella C.B. Clarke & $\mathrm{W}$ \\
\hline & Cyperus congestus $\mathrm{Vahl}$ & $\mathrm{X}$ \\
\hline & Cyperus involucratus Rottb. & $\mathrm{X}$ \\
\hline & Cyperus rotundus $\mathrm{L}$. & $\mathrm{X}$ \\
\hline & Cyperus textilis Thunb. & $\mathrm{W}$ \\
\hline & Mariscus congestus (Vahl) C.B. Clarke & $\mathrm{W}$ \\
\hline Droseraceae & Drosera capensis L. & $\mathrm{W}$ \\
\hline \multirow[t]{2}{*}{ Ericaceae } & Erica glandulosa Thunb. & $\mathrm{W}$ \\
\hline & Erica quadrangularis Salisb. & $\mathrm{W}$ \\
\hline Euphorbiaceae & Mareya aristata Prain & $\mathrm{W}$ \\
\hline \multirow[t]{4}{*}{ Fabaceae } & Crotalaria lanceolata E. Mey. & $\mathrm{X}$ \\
\hline & Dichrostachys cinerea Wight et Arn. & $X$ \\
\hline & Dipogon lignosus (L.) Verdc. & $X$ \\
\hline & Psoralea pinnata $\mathrm{L}$ & $\mathrm{X}$ \\
\hline
\end{tabular}




\begin{tabular}{|c|c|c|}
\hline Family & Species & Status \\
\hline & Tephrosia glomeruliflora Meisn & W \\
\hline & Vachellia karroo (Hayne) Banfi and Galasso & $\mathrm{X}$ \\
\hline & Vachellia nilotica (L.) P.J.H. Hurter and Mabb. & $\mathrm{X}$ \\
\hline \multirow[t]{5}{*}{ Geraniaceae } & Pelargonium capitatum (L.f.) L’Hér. ex Aiton & $\mathrm{X}$ \\
\hline & Pelargonium cordatum L’Hér. & W \\
\hline & Pelargonium panduriforme Eckl. and Zeyh. & W \\
\hline & Pelargonium quercifolium (L.f.) L'Hér. ex Aiton & W \\
\hline & Pelargonium radula (Cav.) L’Hér. & W \\
\hline Haemodoraceae & Wachendorfia thyrsiflora Burm. & $\mathrm{W}$ \\
\hline \multirow[t]{5}{*}{ Hyacinthaceae } & Lachenalia aloides (L.f.) Engl. & W \\
\hline & Lachenalia bulbifera (Cirillo) Asch. and Graebn. & W \\
\hline & Lachenalia mutabilis Sweet & W \\
\hline & Lachenalia reflexa Thunb. & $\mathrm{X}$ \\
\hline & Ornithogalum thyrsoides Jacq. & W \\
\hline Hydrocharitaceae & Lagarosiphon major Ridl. Moss ex Wager & $\mathrm{X}$ \\
\hline \multirow{34}{*}{ Iridaceae } & Aristea ecklonii Baker & W \\
\hline & Babiana disticha Ker Gawl. & W \\
\hline & $\begin{array}{l}\text { Babiana planifolia (G.J. Lewis) Goldblatt and J.C. Manning (syn. } \\
\text { Babiana striata) }\end{array}$ & $\mathrm{W}$ \\
\hline & Babiana tubiflora (L.f.) Ker Gawl. & W \\
\hline & Chasmanthe aethiopica (L.) N.E. Br. & $\mathrm{X}$ \\
\hline & Chasmanthe floribunda (Salisb.) N.E. Br. & $\mathrm{X}$ \\
\hline & Crocosmia $\times$ crocosmiiflora & $\mathrm{X}$ \\
\hline & Dietes grandiflora N.E.Br. & W \\
\hline & Dietes iridioides (L.) Sweet & W \\
\hline & Ferraria crispa Burm. & $\mathrm{X}$ \\
\hline & $\begin{array}{l}\text { Freesia leichtlinii Klatt subsp. alba (G.L. Mey.) J.C. Manning and } \\
\text { Goldblatt [=Freesia alba (G.L. Mey.) Gumbl.] }\end{array}$ & $\mathrm{X}$ \\
\hline & Freesia refracta (Jacq.) Ecklon ex Klatt & W \\
\hline & Gladiolus alatus $\mathrm{L}$. & W \\
\hline & Gladiolus angustus $\mathrm{L}$. & W \\
\hline & Gladiolus carneus F. Delaroche & W \\
\hline & Gladiolus caryophyllaceus (Burm. f.) Poir. & $\mathrm{X}$ \\
\hline & Gladiolus gueinzii Kunze. & W \\
\hline & Gladiolus tristis L. & W \\
\hline & Gladiolus undulatus L. & W \\
\hline & Hesperantha falcata (L.f.) Ker Gawl. & W \\
\hline & Ixia maculata $\mathrm{L}$. & W \\
\hline & Ixia paniculata Delaroche & W \\
\hline & Moraea flaccida (Sweet) Steud. & W \\
\hline & Moraea fugax (D.Delaroche) Jacq. & W \\
\hline & Romulea rosea var. australis (Ewart) M.P.de Vos & $\mathrm{X}$ \\
\hline & Sparaxis bulbifera (L.) Ker-Gawl. & $\mathrm{X}$ \\
\hline & Sparaxis grandiflora Ker Gawl. & W \\
\hline & Sparaxis pillansii L. Bolus & W \\
\hline & Sparaxis tricolor (Schneev.) Ker-Gawl. & W \\
\hline & Tritonia crocata (L.) Ker Gawl. & W \\
\hline & Tritonia gladiolaris (syn. Tritonia lineata) & W \\
\hline & Watsonia borbonica (Pourr.) Goldblatt. & W \\
\hline & Watsonia marginata (L.f.) Ker Gawl. & W \\
\hline & Watsonia meriana (L.) Mill. & $\mathrm{X}$ \\
\hline
\end{tabular}




\begin{tabular}{|c|c|c|}
\hline Family & Species & Status \\
\hline & $\begin{array}{l}\text { Watsonia meriana var. bulbillifera }(=W . \text { bulbillifera } \text { Matthews and } \\
\text { L. Bolus) }\end{array}$ & $\mathrm{W}$ \\
\hline & Watsonia versfeldii J. W. Mathews and L. Bolus & W \\
\hline \multirow[t]{2}{*}{ Juncaceae } & Juncus acutus $\mathrm{L}$. & $\mathrm{X}$ \\
\hline & Juncus effusus L. & $\mathrm{X}$ \\
\hline \multirow[t]{2}{*}{ Lamiaceae } & Leonotis leonurus (L.) R. Br. & W \\
\hline & Plectranthus ecklonii Benth. & $\mathrm{W}$ \\
\hline Liliaceae & Agapanthus praecox Willd. & W \\
\hline Lobeliaceae & Monopsis debilis (L.f.) C. Presl. & W \\
\hline \multirow[t]{2}{*}{ Lythraceae } & Rotala filiformis (Bellardi) Hiern & W \\
\hline & Trapa natans $\mathrm{L}$. & $\mathrm{X}$ \\
\hline Melastomataceae & Dissotis decumbens (P. Beauv.) Triana & W \\
\hline \multirow{2}{*}{ Melianthaceae } & Melianthus comosus Vahl & $\mathrm{W}$ \\
\hline & Melianthus major $\mathrm{L}$. & W \\
\hline Ochnaceae & Ochna serrulata (Hochst.) Walp. & $\mathrm{X}$ \\
\hline \multirow[t]{2}{*}{ Oleaceae } & Jasminum fluminense Vell. & W \\
\hline & Olea europaea subsp. cuspidata (Wall. and G. Don) Cif. & $\mathrm{X}$ \\
\hline Orchidaceae & Disa bracteata Sw. (syn. Monadenia bracteata) & $\mathrm{X}$ \\
\hline \multirow[t]{8}{*}{ Oxalidaceae } & Oxalis compressa Thunb. & W \\
\hline & Oxalis flava $\mathrm{L}$. & W \\
\hline & Oxalis glabra Thunb. & $\mathrm{X}$ \\
\hline & Oxalis hirta L. & $\mathrm{W}$ \\
\hline & Oxalis incarnata $\mathrm{L}$. & W \\
\hline & Oxalis pes-caprae $\mathrm{L}$. & $\mathrm{X}$ \\
\hline & Oxalis purpurata Jacq. & W \\
\hline & Oxalis purpurea $\mathrm{L}$. & $\mathrm{X}$ \\
\hline Phyllanthaceae & Bridelia micrantha (Hochst.) Baill. & W \\
\hline Pittosporaceae & Pittosporum viridiflorum Sims & W \\
\hline Plumbagnaceae & Plumbago auriculata Lam. & W \\
\hline \multirow[t]{22}{*}{ Poaceae } & Andropogon gayanus Kunth & $\mathrm{X}$ \\
\hline & Cenchrus ciliaris L. (syn. Pennisetum ciliare) & $\mathrm{X}$ \\
\hline & Chloris virgata $\mathrm{Sw}$. & $\mathrm{W}$ \\
\hline & Cynodon dactylon (L.) Pers. & $\mathrm{X}$ \\
\hline & Digitaria eriantha Steud. & $\mathrm{X}$ \\
\hline & Echinochloa pyramidalis (Lam.) Hitchc. and Chase & W \\
\hline & Ehrharta calycina $\mathrm{Sm}$ & $\mathrm{X}$ \\
\hline & Ehrharta erecta Lam. & $\mathrm{X}$ \\
\hline & Ehrharta longiflora $\mathrm{Sm}$. & W \\
\hline & Eragrostis curvula (Schrad.) Nees & $\mathrm{X}$ \\
\hline & Eragrostis lehmanniana Nees & $\mathrm{X}$ \\
\hline & Eragrostis plana Nees & $\mathrm{X}$ \\
\hline & Holcus setiger Nees. & $\mathrm{W}$ \\
\hline & Hyparrhenia hirta (L.) Stapf & $\mathrm{X}$ \\
\hline & Hyparrhenia rufa (Nees) Stapf & $\mathrm{X}$ \\
\hline & Imperata cylindrica (L.) P.Beauv. & $\mathrm{X}$ \\
\hline & Megathyrsus maximus (Jacq.) B. K. Simon and S. W. L. Jacobs & $\mathrm{X}$ \\
\hline & Melinis minutiflora $\mathrm{P}$. Beauv. & $\mathrm{X}$ \\
\hline & Melinis repens (Willd.) Zizka & $\mathrm{X}$ \\
\hline & Panicum repens $\mathrm{L}$. & $\mathrm{X}$ \\
\hline & Pennisetum macrourum Trin. & $\mathrm{X}$ \\
\hline & $\begin{array}{l}\text { Pentameris pallida (Thunb.) Galley and H.P. Linder (syn. } \\
\text { Pentaschistis pallida) }\end{array}$ & W \\
\hline
\end{tabular}




\begin{tabular}{|c|c|c|}
\hline Family & Species & Status \\
\hline & Sporobolus natalensis (Steud.) T. Durand and Schinz & $\mathrm{X}$ \\
\hline & Sporobolus pyramidalis Beauv. & $\mathrm{X}$ \\
\hline & Urochloa brizantha (Hochst. ex A. Rich.) R. Webster & W \\
\hline \multirow[t]{3}{*}{ Polygalaceae } & Muraltia heisteria (L.) DC. & W \\
\hline & Polygala myrtifolia $\mathrm{L}$. & $\mathrm{X}$ \\
\hline & Polygala virgata Thunb. & W \\
\hline Polygonaceae & Rumex sagittatus Thunb. & $\mathrm{X}$ \\
\hline Pteridaceae & Pteris dentata subsp. flabellata (Thunb.) Runemark & $\mathrm{W}$ \\
\hline Rhamnaceae & Ziziphus mисronata H. Perrier & W \\
\hline Rutaceae & Agathosma crenulata (L.) Pillans & W \\
\hline \multirow[t]{3}{*}{ Scrophulariaceae } & Dischisma capitatum (Thunb.) Choisy & W \\
\hline & Hebenstretia dentata $\mathrm{L}$. & W \\
\hline & Zaluzianskya divaricata (Thunb.) Walp. & $\mathrm{X}$ \\
\hline \multirow[t]{3}{*}{ Solanaceae } & Lycium ferocissimum Miers & $\mathrm{X}$ \\
\hline & Solanum linnaeanum Hepper and P.-M.L. Jaeger & $\mathrm{X}$ \\
\hline & Solanum sodomaeum $\mathrm{L}$. & W \\
\hline
\end{tabular}

Only taxa marked X clearly fulfilled criteria for listing as "invasive" (sensu Richardson et al. 2000b) in natural or semi-natural ecosystems; those marked with W are listed as "invasive" in other regions by Weber (2017), but do not meet all criteria for listing as invasive sensu Richardson et al. (2000b)

\section{References}

Ansong M, Pergl J, Essl F et al (2019) Naturalized and invasive alien flora of Ghana. Biol Invasions 21:669-683. https://doi.org/10.1007/s10530-018-1860-7

Beaumont LJ, Gallagher RV, Leishman MR et al (2014) How can knowledge of the climate niche inform the weed risk assessment process? A case study of Chrysanthemoides monilifera in Australia. Divers Distrib 20:613-625. https://doi.org/10.1111/ddi.12190

Bossdorf O, Lipowsky A, Prati D (2008) Selection of preadapted populations allowed Senecio inaequidens to invade Central Europe. Divers Distrib 14:676-685. https://doi.org/10.1111/j. 1472-4642.2008.00471.x

Brooks ML, D'Antonio CM, Richardson DM et al (2004) Effects of invasive plants on fire regimes. BioScience 54:677-688. https://doi.org/10.1641/0006-3568(2004)054[0677:EOIAPO]2.0. $\mathrm{CO} ; 2$

Canavan S, Meyerson LA, Packer JG et al (2019) Tall-statured grasses: a useful functional group for invasion science. Biol Invasions 21:37-58. https://doi.org/10.1007/s10530-018-1815-z

D'Antonio CM, Vitousek PM (1992) Biological invasions by exotic grasses, the grass/fire cycle, and global change. Annu Rev Ecol Syst 23:63-87. https://doi.org/10.1146/annurev.es.23. 110192.000431

Dormontt EE, Gardner MG, Breed MF et al (2014) Genetic bottlenecks in time and space: reconstructing invasions from contemporary and historical collections. PLoS One 9:e106874. https://doi.org/10.1371/journal.pone.0106874

Faulkner KT, Hurley BP, Robertson MP et al (2017) The balance of trade in alien species between South Africa and the rest of Africa. Bothalia 47:a2157. https://doi.org/10.4102/abc.v47i2.2157

Foxcroft LC, Pyšek P, Richardson DM, Genovesi P, MacFadyen S (2017) Plant invasion science in protected areas: progress and priorities. Biol Invasions 19:1353-1378. https://doi.org/10.1007/ s10530-016-1367-z

Gaertner M, Biggs R, te Beest M et al (2014) Invasive plants as drivers of regime shifts: identifying high priority invaders that alter feedback relationships. Divers Distrib 20:733-744. https://doi. org/10.1111/ddi.12182 
Guo W-G, van Kleunen M, Winter M et al (2018) The role of adaptive strategies in plant naturalization. Ecol Lett 21:1380-1389. https://doi.org/10.1111/ele.13104

Haeuser E, Dawson W, Thuiller W et al (2018) The European ornamental garden flora as an invasion debt under climate change. J Appl Ecol 55:2386-2395. https://doi.org/10.1111/13652664.13197

Henderson L, Wilson JRU (2017) Changes in the composition and distribution of alien plants in South Africa: an update from the Southern African Plant Invaders Atlas (SAPIA). Bothalia 47: a2142. https://doi.org/10.4102/abc.v47i2.2172

Hickman T, Procheş S, Ramdhani S (2017) Patterns of species richness in two African-centered, aridity-adapted flightless weevil lineages (Coleoptera: Curculionoidea). Zootaxa 4323:593-599. https://doi.org/10.11646/zootaxa.4323.4.12

Inderjit PJ, Pergl J, van Kleunen M et al (2018) Naturalized alien flora of the Indian states: biogeographic patterns, taxonomic structure and drivers of species richness. Biol Invasions 20:1625-1638. https://doi.org/10.1007/s10530-017-1622-y

Kalusová V, Chytrý M, van Kleunen M et al (2017) Naturalization of European plants on other continents: the role of donor habitats. Proc Natl Acad Sci U S A 114:13756-13761. https://doi. org/10.1073/pnas.1705487114

Klaassen E, Kwembeya E (eds) (2013) A checklist of Namibian indigenous and naturalised plants. Occasional Contribution No. 5, National Botanical Research Institute, Windhoek

Kueffer C, Pyšek P, Richardson DM (2013) Integrative invasion science: model systems, multi-site studies, focused meta-analysis, and invasion syndromes. New Phytol 200:615-633. https://doi. org/10.1111/nph.12415

Lafuma L, Balkwill K, Imbert E et al (2003) Ploidy level and origin of the European invasive weed Senecio inaequidens (Asteraceae). Plant Syst Evol 243:59-72. https://doi.org/10.1007/s00606003-0075-0

Manning J, Goldblatt P (2012) Plants of the greater Cape Floristic Region 1: the core Cape flora. Strelitzia 29:1-853

Maroyi A (2012) The casual, naturalised and invasive alien flora of Zimbabwe based on herbarium and literature records. Koedoe 54:Art. \#1054. https://doi.org/10.4102/koedoe.v54i1.1054

Measey J, Robinson TB, Kruger N et al (2020) South Africa as a donor of alien animals. In: van Wilgen BW, Measey J, Richardson DM, Wilson JR (eds) Biological invasions in South Africa. Springer, Berlin, pp 783-826

Moser D, Lenzner B, Weigelt P et al (2018) Remoteness promotes the worldwide invasion of islands. Proc Natl Acad Sci USA 115:9270-9275. https://doi.org/10.1073/pnas.1804179115

Nkuna KV, Visser V, Wilson JRU et al (2018) Global environmental and socio-economic impacts of selected alien grasses as a basis for ranking threats to South Africa. NeoBiota 41:19-65. https://doi.org/10.3897/neobiota.41.26599

Pagad S, Genovesi P, Carnevali L et al (2018) Introducing the global register of introduced and invasive species. Sci Data 5:170202. https://doi.org/10.1038/sdata.2017.202

Pyšek P, Richardson DM, Jarošík V (2006) Who cites who in the invasion zoo: insights from an analysis of the most highly cited papers in invasion ecology. Preslia 78:437-468

Pyšek P, Richardson DM, Pergl J et al (2008) Geographical and taxonomic biases in invasion ecology. Trends Ecol Evol 23:237-244. https://doi.org/10.1016/j.tree.2008.02.002

Pyšek P, Pergl J, Essl F et al (2017) Naturalized alien flora of the world: species diversity, taxonomic and phylogenetic patterns, geographic distribution and global hotspots of plant invasion. Preslia 89:203-274. https://doi.org/10.23855/preslia.2017.203

Pyšek P, Dawson W, Essl F et al (2019) Contrasting patterns of naturalized plant richness in Americas: numbers are higher in the North but expected to rise sharply in the South. Glob Ecol Biogeogr 28:779-783. https://doi.org/10.1111/geb.12891

Razanajatovo M, van Kleunen M, Kreft H et al (2019) Autofertility and self-compatibility moderately benefit island colonization of plants. Glob Ecol Biogeogr 28:341-352. https://doi.org/10. $1111 /$ geb. 12854 
Rejmánek M (2015) Global trends in plant naturalization. Nature 525:39-40. https://doi.org/10. 1038/nature15206

Rejmánek M, Richardson DM (2013) Trees and shrubs as invasive alien species - 2013 update of the global database. Divers Distrib 19:1093-1094. https://doi.org/10.1111/ddi.12075

Richardson DM, Cowling RM (1992) Why is mountain fynbos invasible and which species invade? In: van Wilgen BW, Richardson DM, Kruger FJ et al (eds) Fire in South African mountain fynbos. Springer, Berlin, pp 161-181. https://doi.org/10.1007/978-3-642-76174-4_9

Richardson DM, Rejmánek M (2011) Trees and shrubs as invasive alien species - a global review. Divers Distrib 17:788-809. https://doi.org/10.1111/j.1472-4642.2011.00782.x

Richardson DM, Thuiller W (2007) Home away from home - objective mapping of high-risk source areas for plant introductions. Divers Distrib 13:299-323. https://doi.org/10.1111/j.14724642.2007.00337.x

Richardson DM, Macdonald IAW, Hoffmann JH et al (1997) Alien plant invasions. In: Cowling RM, Richardson DM, Pierce SM (eds) Vegetation of Southern Africa. Cambridge University Press, Cambridge, pp 535-570

Richardson DM, Allsopp N, D'Antonio CM et al (2000a) Plant invasions: the role of mutualisms. Biol Rev 75:65-93. https://doi.org/10.1017/S0006323199005435

Richardson DM, Pyšek P, Rejmánek M et al (2000b) Naturalization and invasion of alien plants: concepts and definitions. Divers Distrib 6:93-107. https://doi.org/10.1046/j.1472-4642.2000. 00083.x

Richardson DM, Rouget M, Ralston SJ et al (2005) Species richness of alien plants in South Africa: environmental correlates and the relationship with indigenous plant species richness. Ecoscience 12:391-402. https://doi.org/10.2980/11195-6860-12-3-391.1

Richardson DM, Foxcroft LC, Latombe G et al (2020) The biogeography of South African terrestrial plant invasions. In: van Wilgen BW, Measey J, Richardson DM, Wilson JR, Zengeya TA (eds) Biological invasions in South Africa. Springer, Berlin, pp 65-94

Rouget M, Robertson MP, Wilson JRU et al (2016) Invasion debt: quantifying future biological invasions. Divers Distrib 22:445-456. https://doi.org/10.1111/ddi.12408

Rundel PW, Dickie IE, Richardson DM (2014) Tree invasions into treeless areas: mechanisms and ecosystem processes. Biol Invasions 16:663-675. https://doi.org/10.1007/s10530-013-0614-9

Setshogo MP (2005) Preliminary checklist of the plants of Botswana. SABONET Report No. 37, Pretoria and Gaborone

South African National Biodiversity Institute (2016) Botanical Database of Southern Africa (BODATSA). www.newposa.sanbi.org/ accessed on 11 April 2019

Thuiller W, Richardson DM, Pyšek P et al (2005) Niche-based modelling as a tool for predicting the risk of alien plant invasions at a global scale. Glob Change Biol 11:2234-2250. https://doi.org/ 10.1111/j.1365-2486.2005.001018.x

van Kleunen M, Johnson SD (2007) South African Iridaceae with rapid and profuse seedling emergence are more likely to become naturalized in other regions. J Ecol 95:674-681. https:// doi.org/10.1111/j.1365-2745.2007.01250.x

van Kleunen M, Johnson SD, Fischer M (2007) Predicting naturalization of southern African Iridaceae in other regions. J Appl Ecol 44:594-603. https://doi.org/10.1111/j.1365-2664.2007. 01304.x

van Kleunen M, Manning JC, Pasqualetto V (2008) Phylogenetically independent associations between autonomous self-fertilization and plant invasiveness. Am Nat 171:195-201. https://doi. org/10.1086/525057

van Kleunen M, Dawson W, Essl F et al (2015) Global exchange and accumulation of non-native plants. Nature 525:100-103. https://doi.org/10.1038/nature14910

van Kleunen M, Pyšek P, Dawson W et al (2019) The Global Naturalised Alien Flora (GloNAF) database. Ecology 100:e0242

van Wilgen BW, Measey J, Richardson DM et al (2020) Biological invasions in South Africa: an overview. In: van Wilgen BW, Measey J, Richardson DM, Wilson JR, Zengeya TA (eds) Biological invasions in South Africa. Springer, Berlin, pp 3-30 
Vilà M, Basnou C, Pyšek P et al (2010) How well do we understand the impacts of alien species on ecosystem services? A pan-European, cross-taxa assessment. Front Ecol Environ 8:135-144. https://doi.org/10.1890/080083

Vilatersana R, Sanz M, Galian A et al (2018) The invasion of Senecio pterophorus across continents: multiple, independent introductions, admixture and hybridization. Biol Invasions 18:2045-2065. https://doi.org/10.1007/s10530-016-1150-1

Vinogradova Y, Pergl J, Hejda M et al (2018) Naturalized alien plants of Russia: insights from regional inventories. Biol Invasions 20:1931-1943. https://doi.org/10.1007/s10530-018-1686-3

Visser V, Wilson JRU, Fish L et al (2016) Much more give than take: South Africa as a major donor but infrequent recipient of invasive non-native grasses. Glob Ecol Biogeogr 25:679-692. https:// doi.org/10.1111/geb.12445

Wardill TJ, Graham GC, Zalucki M et al (2005) The importance of species identity in the biocontrol process: identifying the subspecies of Acacia nilotica (Leguminosae: Mimosoideae) by genetic distance and the implications for biological control. J Biogeogr 32:2145-2159. https://doi.org/ 10.1111/j.1365-2699.2005.01348.x

Weber E (2017) Invasive plant species of the World, 2nd edn. CABI, Wallingford

Wilson JR, Foxcroft LC, Geerts S et al (2020) The role of environmental factors in promoting and limiting biological invasions in South Africa. In: van Wilgen BW, Measey J, Richardson DM, Wilson JR, Zengeya TA (eds) Biological invasions in South Africa. Springer, Berlin, pp 353-384

Open Access This chapter is licensed under the terms of the Creative Commons Attribution 4.0 International License (http://creativecommons.org/licenses/by/4.0/), which permits use, sharing, adaptation, distribution and reproduction in any medium or format, as long as you give appropriate credit to the original author(s) and the source, provide a link to the Creative Commons licence and indicate if changes were made.

The images or other third party material in this chapter are included in the chapter's Creative Commons licence, unless indicated otherwise in a credit line to the material. If material is not included in the chapter's Creative Commons licence and your intended use is not permitted by statutory regulation or exceeds the permitted use, you will need to obtain permission directly from the copyright holder.

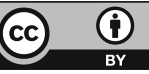

